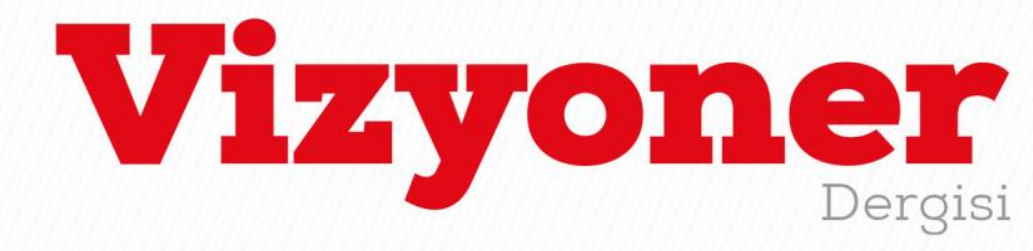

Süleyman Demirel Üniversitesi Vizyoner Dergisi, Yıl: 2022, Cilt: 13, Sayı: 33, 110-121.

Süleyman Demirel University Visionary Journal, Year: 2022, Volume: 13, No: 33, 110-121.

\title{
EVALUATION OF RESEARCH UNIVERSITIES' THIRD MISSION IN TURKEY
}

\section{TÜRKIYE'DEKİ ARAŞTIRMA ÜNIVERSITELERININ ÜÇÜNCÜ MISYONLARININ DEĞERLENDİRILMESI}

\author{
Asst. Prof. Dr. Aslı GÜNAY ${ }^{1}$ \\ Prof. Dr. Murat Ali DULUPÇU ${ }^{2}$
}

\begin{abstract}
This study aims to evaluate the efficiency performance of third mission activities of research universities in Turkey regarding their social dimension, which has become prominent in recent years. Data Envelopment Analysis was used to evaluate the efficiency of the third mission of universities for 2019. The findings show that the number of relatively efficient research universities is only four out of sixteen, and the overall mean score of universities is 0.422 . Thus, in total, universities are inefficient regarding their third mission activities as of 2019. Besides, in order to get reasonable results, a Tobit model was applied to examine the extent to which exogenous factors influence the third mission efficiencies of research universities in Turkey. The results indicate that only the foundation year has a significantly positive impact on university efficiency; in other words, the possibility of third mission efficiency is greater for the older ones, which were founded before 1981. The university ranking was used as a proxy for external factors affecting both the research mission and the third mission of research universities. No significant linkage between the performance of the third mission activities conducted within the scope of social dimension and the research mission of research universities is determined for Turkey.
\end{abstract}

Keywords: Data Envelopment Analysis, Efficiency, Research University, Tobit Model, Third Mission of the University.

JEL Classification Codes: I23, I21, L25, D61.

ÖZ

$\mathrm{Bu}$ çalışma, Türkiye'deki araştırma üniversitelerinin üçüncü misyon faaliyetlerinin etkinlik performanslarını son yıllarda öne çıkan toplumsal boyut açısından değerlendirmeyi amaçlamaktadır. Araştırma üniversitelerinin 2019 yılı için üçüncü misyonları kapsamında yürüttükleri faaliyetlerin etkinliklerini ölçmek için Veri Zarflama Analizi uygulanmıştır. Bulgular, on altı üniversiteden sadece dördünün üçüncü misyon faaliyetlerini etkin bir şekilde yürüttüklerini ortaya koymuştur. Ayrıca üniversitelerin genel ortalama etkinlik puanı 0.422 olduğundan, tüm araştırma üniversiteleri birlikte değerlendirildiğinde bu üniversitelerin üçüncü misyonlarının toplumsal boyuta göre etkin olmadıkları görülmektedir. Bunun yanı sıra, araştırma üniversitelerinin üçüncü misyon faaliyetlerinin etkinliğini etkileyen dışsal faktörleri belirlemek için Tobit modeli kullanılmıştır. Bulgular kuruluş yılının üniversitelerin üçüncü misyon faaliyetlerini pozitif yönde etkilediğini bir başka değişle 1981 yılından önce kurulan araştırma üniversitelerinin topluma hizmet faaliyetlerini daha etkin yürütme potansiyeline sahip olduklarını ortaya koymuştur. Böylelikle, Türkiye'de araştırma üniversitelerinin üçüncü misyonlarının toplumsal boyutu kapsamında yürütülen faaliyetlerin performansı ile araştırma misyonları arasında önemli bir bağlantı bulunamamıştır.

Anahtar Kelimeler: Araştırma Üniversitesi, Etkinlik, Tobit Model, Üniversitenin Üçüncü Misyonu, Veri Zarflama Analizi. JEL Sınıflandırma Kodları: I23, I21, L25, D61.

\footnotetext{
(D) Social Sciences University of Ankara, Faculty of Political Science, Department of Economics, asli.gunay@asbu.edu.tr

2 (D) Süleyman Demirel University, Faculty of Economics and Administrative Sciences, Department of Economics, muratdulupcu@sdu.edu.tr

Makale Geliş Tarihi / Received : : 06.09 .2021

Makale Kabul Tarihi / Accepted $\quad$ : 17.01 .2022 


\section{GENIȘLETILMIȘ ÖZET}

\section{Amaç ve Kapsam:}

Son yıllarda üniversitelerin "eğitim" ve "araştırma" misyonlarını yerine getirmelerinin yanı sıra "topluma hizmet" olarak adlandırılan üçüncü bir misyonu yerine getirmelerine yönelik dolaylı bir baskı ile karşı karşıya kaldıkları gözlenmektedir. Bununla birlikte, üniversitelerin üçüncü misyon faaliyetleri üç boyutta gruplandırılmaktadır: araştırma (teknolojik transfer ve inovasyon), eğitim (hayat boyu öğrenme) ve sosyal ve kültürel hayata katılım. Ancak yükseköğretimde üniversitelerin üçüncü misyonları kapsamında yürüttükleri faaliyetleri üniversitenin araştırma ve eğitim faaliyetlerinden ayırmak kolay değildir. Çünkü günümüzde girişimci ve tematik üniversite modellerinin, üniversiteler tarafından üniversite-sanayi işbirliği kapsamında yürütülen çalışmaların, inovasyon ve teknoloji transfer çalışmalarının yükseköğretimde üniversitelerin üçüncü misyon faaliyetleri ile ne ölçüde kesiştiği ayrı bir tartışma konusudur. Türkiye'de üniversitelerin araştırma üniversitesi statüsü kazanması yeni bir süreç olduğundan üniversitelerin araştırma misyonları ile üçüncü misyonlarını ne ölçüde ayrıştırabildikleri bu çalışmanın çıkış noktalarından biridir. Bu kapsamda çalışmanın amaçları: (i) araştırma üniversitelerinin üçüncü misyonlarının toplumsal boyutu kapsamında yürüttükleri faaliyetlerinin göreli etkinliklerini incelemek; (ii) araştırma üniversitelerinin üçüncü misyon faaliyetlerinin etkinliklerini etkileyen dışsal faktörleri (üniversitenin kuruluş yıl1, bulunduğu şehir, tıp fakültesi ve uluslararası üniversite sıralaması) belirlemektir. Literatürde üniversitelerin üçüncü misyon faaliyetlerinin etkinliğine yönelik yapılan çalışmaların araştırma ve eğitim üzerine yapılan çalışmalara kıyasla azlığı dikkate alındığında yapılan bu çalışmanın bu alandaki noksanlığa katkıda bulunacağı öngörülmektedir. Özellikle bu çalışmanın öncelikli misyonu araştırma yapmak olan araştırma üniversiteleri bazında yapılmasının üniversitelerin araştırma misyonları ve üçüncü misyonları kapsamında yürüttükleri faaliyetlerin ne ölçüde örtüştüğü ya da ayrıştığı tartışmasına bir ışık tutabileceği düşünülmektedir.

Yöntem:

Bu çalışmada öncelikle Türkiye'de 2017 yılında Yükseköğretim Kurulu (YÖK) tarafından ilan edilen on bir araştırma üniversitesi ve beş aday araştırma üniversitesinin üçüncü misyonlarının toplumsal boyutu kapsamında yürüttükleri faaliyetlerin göreli etkinlikleri hesaplanmıştır. Üniversitelerin 2019 yılı için etkinlik değerlerinin hesaplanmasında Veri Zarflama Analizi (VZA) yöntemi kullanılmıştır. YÖK tarafından yıllık olarak yayınlanan Üniversite İzleme ve Değerlendirme Raporları Türkiye'de üniversitelerin üçüncü misyonlarının toplumsal boyutu kapsamında yürüttükleri faaliyetlerin topluma hizmet başlığı altında yer aldığını göstermektedir. Ayrıca, dışsal faktörlerin araştırma üniversitelerinin üçüncü misyonları kapsamında yürüttükleri topluma hizmet faaliyetlerinin etkinliği üzerine etkisini belirlemek için Tobit Modeli uygulanmıştır. Çalışmada kullanılacak girdi ve çıktılar öncelikle mevcut verilerin ulaşılabilirliği ve güvenilirliği dikkate alınarak belirlenmiştir. Bu kapsamda araştırma üniversitelerine ait toplam öğrenci sayısı, öğretim elemanı sayısı ve üniversite bütçesi girdi olarak kullanılırken sosyal sorumluluk projesi sayısı ile üniversitenin sürekli eğitim merkezi ve dil merkezlerinde verilen sertifika sayısı gibi üniversiteler tarafından yalnızca topluma hizmet kapsamında yürütülen faaliyetler çıktı olarak kullanılmıştır.

Bulgular:

Bulgular, 2019 yılında Türkiye'de ki üç araştırma üniversitesinin ve bir aday araştırma üniversitesinin üçüncü misyonları kapsamında yürüttükleri topluma hizmet faaliyetleri için beşeri sermaye ve mali girdilerini etkin kullandığını ortaya koymuştur. Ayrıca üniversitelerin genel ortalama etkinlik puanı 2019 yılında 0,422 olduğundan, tüm üniversiteler birlikte değerlendirildiğinde araştırma üniversitelerinin üçüncü misyonlarının toplumsal boyut kapsamında yürüttükleri faaliyetlerin etkin olmadıkları görülmektedir. Bunun yanı sıra, araştırma üniversitelerinin üçüncü misyonlarının etkinliğini etkileyen dışsal faktörleri belirlemek için uygulanan Tobit modeli sonuçlarına göre üniversitelerin kuruluş yılının üniversitelerin üçüncü misyon faaliyetlerini pozitif yönde etkilediği bir başka değişle 1981 yılından önce kurulan araştırma üniversitelerinin üçüncü misyon faaliyetlerini daha etkin yürütme potansiyeline sahip oldukları ortaya konmuştur. Ancak araştırma üniversitelerinin Türkiye'de üç büyükşehirde (Ankara, İstanbul ve İzmir) kurulmasının ve tıp fakültesine sahip olmasının bu üniversitelerin üçüncü misyon faaliyetlerinin performansına önemli bir katkı sağlamadığı görülmektedir. Araştırma üniversitelerinin temel misyonu araştırma olduğundan Times Higher Education (THE) uluslararası üniversite sıralaması üniversitelerin üçüncü misyonu ve araştırma misyonu arasındaki bağlantıyı incelemek için vekil olarak kullanılmıs olup, bulgular üniversite sıralamasının Türkiye'de araştırma üniversitelerinin üçüncü misyon faaliyetlerinin performansına önemli bir katkısı olmadığını ortaya koymuştur. Bir başka ifadeyle, Türkiye'de araştırma üniversitelerinin üçüncü misyonlarının toplumsal boyutu kapsamında yürütülen faaliyetlerin performansı ile araştırma misyonları arasında önemli bir bağlantı bulunamamıştır.

\section{Sonuç ve Tartışma:}

Araştırma üniversitelerinin temel misyonu araştırma olmakla birlikte üniversiteler tarafindan yürütülen üçüncü misyon faaliyetlerinin bir kısmının araştırma faaliyetleri ile ilişkili olduğu fakat bu hususta net bir ayırım yapılamadığı görülmektedir. $\mathrm{Bu}$ çalışmada üniversitelerin üçüncü misyon faaliyetlerinin ağırlıklı olarak toplumsal boyutu ele alınmış olup, çalışmanın içeriği araştırma üniversitelerinin üçüncü misyonunun araștırma boyutu da dahil edilerek genişletilebilinir. Son yıllarda YÖK ve Yükseköğretim Kalite Kurulu (YÖKAK) üniversitelerin topluma hizmet faaliyetlerine yönelik veriler toplamaya başlamış olup, bu durumun Türkiye'de üniversitelerin üçüncü misyon performanslarının ölçümüne önemli bir katk1 sağlayacağ öngörülmektedir. Ayrıca, bu çalışmanın bulgularının Türkiye'de araştırma üniversitelerinin yöneticilerine üçüncü misyonları kapsamında yürüttükleri topluma hizmet faaliyetlerinin performansını artırmada yol gösterici olabileceği düşünülmektedir. Diğer yandan, Türkiye'de araştırma üniversiteleri çok uzun bir geçmişe sahip olmadığından üniversite yönetimlerinin araştırma faaliyetlerinin yanı sıra topluma hizmet faaliyetlerine ne ölçüde önem vermek isteyeceği ayrı bir tartışma konusudur. 
Süleyman Demirel Üniversitesi Vizyoner Dergisi, Yıl: 2022, Cilt: 13, Sayı: 33, 110-121.

Süleyman Demirel University Visionary Journal, Year: 2022, Volume: 13, No: 33, 110-121.

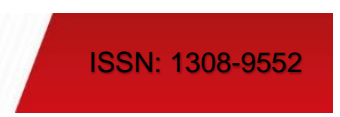

\section{INTRODUCTION}

Although teaching and research have long been the primary missions of universities, a third mission generally known as "contribution to society" has emerged in recent years (Compagnucci \& Spigarelli, 2020; Rubens, Spigarelli et al., 2017; Urdari et al., 2017; Spiel, 2017; Brundenius \& Göransson, 2011). According to Marhl and Pausits (2011), the third mission is as a vehicle for universities to remain in the ivory tower even while improving collaboration and exchange with society. As a result, universities' third mission is to contribute to regional socioeconomic development through fostering relationships and knowledge transformation between universities and society, as well as non-university stakeholders in their region (Frondizi et al., 2019; Mora et al., 2015; Agasisti et al., 2019).

The third mission of universities is an ambiguous concept in contrast to the other well-known missions of teaching and research, since it has several dimensions (Laredo, 2007). While the processes and structures related to teaching and research are pretty clearly defined and studied, the third mission is a difficult task due to the challenges of putting it into effect and complicated measurement methods (Papadimitriou, 2020). However, there are two main approaches to defining the third mission of universities. The first one is the "triple helix" model, which analyses relationships between universities, industry, and government. It claims that universities can promote innovation and economic development in a knowledge-based society (Leydesdorff \& Etzkowitz, 1996). The comprehensive and repeating notions of "entrepreneurial university" and "technology transfer" are also now part of this approach (Trencher et al., 2014). The second one refers to all activities that generate, use, apply, or transfer knowledge outside the university (Molas-Gallart \& Castro-Martinez, 2007; Urdari et al., 2017). However, the activities of the third mission can be grouped into three categories: research (technological transfer and innovation), teaching (lifelong learning), and social engagement (Carrion et al., 2012; Compagnucci \& Spigarelli, 2020; Marhl \& Pausits, 2011). In this context, facilities conducting research in technology transfer offices (TTOs), incubators, and technoparks to create direct and indirect mechanisms to link universities to businesses can be defined as research activities regarding the third mission. Additionally, curriculum alignment to society's demands, distance education, the commercialization of facilities, certificate programs, and the hosting of conferences are all examples of activities in teaching. Moreover, personnel services, summer schools for employees' children, courses offered to university staff, and sports and cultural activities are all examples of social engagement activities (Montesinos et al., 2008). Therefore, all activities related to lifelong learning and social engagement in universities can be defined as the social dimension of third mission in addition to the research dimension (Günay, 2021).

Furthermore, research universities are described as academic institutions dedicated to the creation and transmission of knowledge across a wide range of disciplines and fields, with the appropriate infrastructure to allow for the highest quality of education and research (Altbach, 2009). These universities, on the other side, are intended to place a greater emphasis on research-related activities. In addition to research-related activities, research universities often seek to address and focus on social issues (Alliance of Turkish Research Universities [ALTRU], 2016). Since they are more involved in consultancy activities, especially with small and medium enterprises (SMEs), industry, and government, research universities are involved in various third mission activities with them, such as research projects, consulting services, patents, copyright, industrial design, and trade marks (Sánchez Barrioluengo et al., 2016). It is consequently more vital than ever to look into the connections between research mission and third mission activities (Innocenti et al., 2019).

In Turkey, officially classifying universities as "research universities" is a new phenomenon. The massive expansion of Turkey's higher education system since 2006 has necessitated enhancing university differentiation and ensuring the efficient use of all resources. Today, the number of universities is 203 and the number of higher education students is more than 8 million and 2 hundred thousand (Council of Higher Education [CoHE], 2021a). In this context, Turkish research universities were identified through the CoHE's mission differentiation and specialization studies as among the country's existing, long-established universities in 2017 (CoHE, 2020).

Besides, the contribution to society activities of universities as a part of their third mission has been widely reported in the Turkish universities' strategic plan reports in recent years. In this context, some objectives and performance criteria have been defined for improving and increasing the performance of universities' contribution to society activities. Furthermore, the CoHE has been publishing "University Monitoring and Evaluation Reports" since 2019, composed of 45 indicators under five main categories, and one of them is labelled as the "contribution to society and responsibility" category (CoHE, 2021b). Similarly, the Turkish Higher Education Quality Council (THEQC) publishes "Institutional Indicator Reports" under five main headings, and one of them is "service to 
society" (THEQC, 2021). Therefore, it is evident that in Turkey, as in many other countries, universities' contribution to society activities have begun to be considered as one of the most important performance criteria in higher education. Moreover, the CoHE has presented high achievement awards in the contribution to society category as a part of their third mission since 2017 to encourage Turkish universities to engage in activities and projects relevant to this subject (CoHE, 2021c). It can be said that third mission activities are carried out and monitored through the social dimension of third mission activities in the Turkish higher education system.

The main objective of this study is to evaluate the performance of the third mission activities of research universities in Turkey within the scope of the social dimension. In this context, the connections between the research mission and the third mission of Turkish research universities might be intensively investigated. Here, Data Envelopment Analysis (DEA) was utilized to estimate the efficiency of the third mission activities, and the Tobit model was applied to analyse the determinants of efficiency in research universities in Turkey. When the shortage of studies measuring and investigating the performance of third mission activities in higher education is considered, the study might fill a gap in the literature. Also, the findings of this study might provide managerial information and act as a guide for research university administrators in Turkey to efficiently allocate their resources to improve and enhance their third mission activities from a policy standpoint.

The following is how the rest of the paper is organized: The next section presents a review of literature on university efficiency and performance measurement. The methodology is explained in section three, and the data is presented in section four. In section five, empirical findings are given. Finally, the study is concluded in the last section.

\section{LITERATURE}

Efficiency is a measurement tool that assesses how well a company's or organization's actions are linked with its strategic goals (Weihrich \& Koontz, 2005). In particular, efficiency is a critical issue for people in charge of public services, and especially university efficiency, has gotten a lot of attention in the last several decades in three main contexts: financial efficiency (Günay \& Dulupçu, 2019; Kuo \& Ho, 2008; Tran \& Villano, 2018); teaching efficiency (Agasisti \& Bonomi, 2014; Abbott \& Doucouliagos, 2003; Barra \& Zotti, 2016; Mikušová, 2017; Baysal et al., 2005; Yeşilyurt, 2009), and research efficiency (Johnes \& Yu, 2008; Johnes \& Johnes, 1995; Munoz, 2016; Ng \& Li, 2000; Günay \& Yüksel-Haliloğlu, 2018; Karacabey, 2001).

Since universities are non-profit organizations and motivated by different goals, measuring the efficiency of universities is difficult due to their characteristic features. Firstly, universities have multiple inputs and outputs, so measuring the impact of each input on each output individually becomes difficult. Second, some university outputs cannot be measured quantitatively, such as skill development, socialization, etc. (Worthington, 2001; Engert, 1996; Günay \& Yüksel-Haliloğlu, 2018).

Due to changing stakeholder and government expectations of what universities can deliver over the last few decades, there has been an increased emphasis on enhancing the performance of universities' third mission activities (Zomer \& Benneworth, 2011). While many studies focus on universities' efficiency in research and teaching missions, there are few studies on third mission efficiency, owing to a lack of data and the difficulty of defining and measuring third mission activities (Giuri et al., 2019; Innocenti et al., 2019; Urdari et al., 2017). Setting criteria and identifying the impacts to be measured, according to Rosli and Rossi (2016), is relatively difficult. Furthermore, according to Frondizi et al. (2019), universities are reluctant to focus more on third mission activities within the scope of the social dimension because the total weight of these activities in the leading international rankings is minimal or none.

In this context, Urdari et al. (2017) analyzed the methods of measurement used by global university rankings and their relation to universities' third mission activities. Besides, Rubens et al. (2017) examined how universities fulfill their third mission as entrepreneurial universities. According to Jaeger and Kopper (2014), there is a strong link between universities' emphasis on education and research on the one hand and regional economic structure on the other, suggesting that universities' regional engagement and third mission activities have a greater potential. Moreover, Knudsen et al. (2019) identified some models of how universities aim to accomplish their third mission. According to Kesten (2019) and Günay (2021), universities in Turkey have adopted the third mission notion to some extent in recent years, owing to the pressure of the CoHE, but they need to do more in terms of the social dimension activities. In particular, Günay (2021) evaluated the efficiency of the third mission activities of regional 
development-oriented universities in Turkey with regard to the social dimension of third mission activities. While Mammadov and Aypay (2019) investigated the overall efficiency of research universities in Turkey, there is no study that examines the efficiency of third-mission activities of Turkish research universities.

Few studies, on the other hand, have looked at the relationship between universities' research missions and their third missions. Innocenti et al. (2019) found higher positive correlations between the third mission and research mission at more research-oriented universities. According to preliminary research conducted as part of this study, there is no study on the efficiency of universities in Turkey that focuses on both these dual missions. This study tried to look at the relationship between the activities carried out within the scope of these two missions, although indirectly. So, this research might help to close this gap in the literature.

\section{METHODOLOGY}

\subsection{DEA}

The DEA allows for the comparison of various inputs and outputs as a non-parametric application. DEA is a linear programming-based technique for measuring the relative performance of decision-making units (DMU) at any time when comparing inputs and outputs with different measurement units (Karacaer, 1998). DMUs are chosen as institutions that must employ the same inputs to create the same outputs and have the same objectives (Oruç et al., 2014).

The DEA model in this study is formulated concerning the constant returns to scale assumption; hence, it is expected that when inputs are increased proportionately, outputs will also rise by the same ratio without any change in the composition of DMUs' inputs (Oruç et al., 2014). Each DMU has $m$ inputs and $s$ outputs, and there are $n$ DMUs to evaluate. An output-oriented model was set up to obtain the optimal level of third mission outputs while not altering universities' inputs related to third mission activities since an output-oriented approach focuses on maximizing outputs while retaining the same level of inputs (Matthews \& Mahadzir, 2006). The Charnes, Cooper and Rhodes (CCR) DEA model's output formula is as follows (Charnes et al., 1978; Charnes et al., 1994):

$\operatorname{Min} h_{k}=\sum_{k=1}^{m} v_{i k} X_{i k}$

Constraints:

$\sum_{r=1}^{s} u_{r k} Y_{r k}-\sum_{i=1}^{m} v_{i k} X_{i j} \leq 0 ; k=1, \ldots \ldots, n$

$\sum_{i=1}^{m} u_{r k} Y_{r k}=1$

$u_{r k} \geq \varepsilon>0 ; r=1, \ldots \ldots, s$

$v_{i k} \geq \varepsilon>0 ; i=1, \ldots \ldots, m$

where the $k_{t h}$ DMU uses $x_{i k}$ units of input $i$ to produce $y_{r k}$ units of output $r$ and their weights are represented by $v_{i k}$ and $u_{r k}$, respectively.

\subsection{Tobit Model}

Tobin (1958) developed the Tobit model, which is used to determine the variables that influence the DEA's efficiency scores. Because of the censored dependent variable of institutional efficiency, the Tobit model is favoured over OLS regression to exclude the impacts of variables that can be observed but not assessed (Hsiao et al., 2010; Kao et al., 2011). In this case, the Tobit model's mathematical formula is defined (Tobin, 1958; Bierens, 2014):

$y_{j}^{*}=x_{j} \propto+e_{j}$

where $y_{j} *$ is a latent variable as in a linear regression model, and $x_{j}$, is the vector of the explanatory variable. The relationship between $y_{j} *$ and $x_{j}$ is determined by the unobservable vector $(\alpha)$. Under the normal distribution assumption, $e_{j}$ is the error term. 
Süleyman Demirel Üniversitesi Vizyoner Dergisi, Yıl: 2022, Cilt: 13, Sayı: 33, 110-121.

Süleyman Demirel University Visionary Journal, Year: 2022, Volume: 13, No: 33, 110-121.

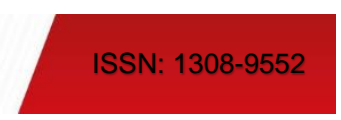

\section{DATA}

On the basis of mission differentiation and specialization studies, the CoHE categorized sixteen public universities in Turkey as either research universities or candidate research universities in 2017. Although the main objective of research universities is to promote the universities' research mission activities to become world-class universities, carrying out third mission activities in their regions with the government, industry, and society is also important due to the research and social dimension of universities' third mission. Hence, the research mission and the third mission activities of research universities might be related or complement each other. For this reason, research universities in Turkey were selected as DMUs for this study. Due to a lack of data for investigating the research dimension, the data set for 2019 was used to assess the relative efficiency performance of these universities' third mission activities, particularly on the basis of social dimension. Table 1 presents the inputs and outputs that were considered in this study.

Table 1. Inputs and Outputs

\begin{tabular}{cc}
\hline Inputs & Outputs \\
\hline Number of academic personnel (total) & Number of social responsibility projects \\
Number of students (total) & Number of certificates issued by the Continuous \\
University budget (total) & Education Center and Language Center \\
\hline
\end{tabular}

According to Carrion et al. (2012), the number of academic personnel, students who participate in social engagement activities, and the university budget allocated to third mission activities are classified among the set of social dimension indicators to measure the third mission activities of universities. Hence, academic personnel, students and the university budget were selected as human capital inputs and financial inputs, respectively, as proxy variables for social dimension indicators. The number of academic personnel and students (including all undergraduate and graduate students) was taken from the Higher Education Statistics published by the CoHE (CoHE, 2021a). Public research universities in Turkey are funded through the annual central government budget, and the total budget amount for universities was obtained from the National Education Statistics published by the Ministry of National Education (MoNE) (MoNE, 2019).

Third mission outputs are annually published in "University Monitoring and Evaluation Reports" by the CoHE. There are eight indicators in this report for the "contribution to society and responsibility" category: the number of university's social projects, the number of certificates given through the Continuous Education Center (CEC) and Language Center, the number of activities carried out for students and graduates by the Career Center, the number of activities on social integration and inclusion for disadvantaged groups, the number of the university's barrier-free university awards, barrier-free flag award, barrier-free program medal, and disability-friendly award, the number of awards received by the university in the fields of zero waste, green campus, and environmentalism, and the ranking of the university in the greenmetric index. On the other hand, the THEQC indicators for evaluating the third mission of universities are the number of service to society projects carried out by the university, the CEC's annual hours of education, and the number of people receiving training through the CEC, Lifelong Learning Centre, etc.

Since the common indicators in the two reports for the third mission activities are social responsibility projects and training provided by CECs, the university's number of social projects and the number of certificates given through the Continuous Education Center (CEC) and Language Center were used as the third mission outputs in this study (CoHE, 2021b). Data availability is one main reason why only these two outputs were chosen among others. The other one is that the social dimension of the third mission activities of universities in Turkey are conducted mainly by the Continuous Education Centre. In addition, the DEA model rule, which was developed to calculate the link between the number of universities and the number of inputs and outputs, $[(\mathrm{m}+\mathrm{s}) \leq \mathrm{n} / 3]$, where $\mathrm{m}$ is the number of inputs, $\mathrm{s}$ the number of outputs, and $\mathrm{n}$ the number of universities (Banker, Charnes and Cooper, 1984), implies that only two outputs can be used for analysis. While the Win4DEAP software package program, developed by Coelli (1996), was used to perform the DEA calculations, the Tobit model regressions were done using the EViews 10 software package program. 


\section{EMPIRICAL FINDINGS}

Efficiency analysis results for the third mission regarding the social dimension of research universities in Turkey are displayed in Table 2. Regarding the third mission activity efficiency, overall universities' mean score in 2019 was 0.422 . Also, the number of relatively efficient universities was only four out of sixteen universities in 2019 . Overall, research universities in Turkey were inefficient in terms of third mission activities considering a social dimension. Moreover, eleven universities' efficiency scores were below the mean value in 2019. While Ankara University, Erciyes University, and Istanbul Technical University are the best performing research universities with regard to their third mission activities, Ege University is the only efficient research candidate university among them. Thus, it is obvious that both human and financial resources have not been used efficiently for the third mission activities related to the social dimension in the research universities in Turkey along with the regional development-oriented universities (Günay, 2021).

Table 2. Third Mission Efficiency Scores of Research Universities

\begin{tabular}{|c|c|c|c|}
\hline & University & Foundation Year & Efficiency Score \\
\hline \multirow{11}{*}{ Research University } & Ankara University & 1946 & 1.000 \\
\hline & Bogazici University & 1971 & 0.835 \\
\hline & Erciyes University & 1978 & 1.000 \\
\hline & Gazi University & 1982 & 0.267 \\
\hline & Gebze Technical University & 1992 & 0.045 \\
\hline & Hacettepe University & 1967 & 0.096 \\
\hline & Istanbul Technical University & 1944 & 1.000 \\
\hline & Istanbul University & 1933 & 0.330 \\
\hline & Istanbul University-Cerrahpasa & 2018 & 0.011 \\
\hline & Izmir Institute of Technology & 1992 & 0.172 \\
\hline & Middle East Technical University & 1956 & 0.206 \\
\hline \multirow{5}{*}{ Candidate University } & Bursa Uludag University & 1975 & 0.107 \\
\hline & Cukurova University & 1973 & 0.076 \\
\hline & Ege University & 1955 & 1.000 \\
\hline & Selcuk University & 1975 & 0.361 \\
\hline & Yildiz Technical University & 1982 & 0.243 \\
\hline \multicolumn{3}{|c|}{ Mean } & 0.422 \\
\hline \multicolumn{3}{|c|}{$E=1$} & 4 \\
\hline \multicolumn{3}{|c|}{$\mathrm{E}<1$} & 12 \\
\hline
\end{tabular}

The mean efficiency scores of universities, listed in Table 2, were used as a dependent variable in the Tobit model analysis (Table 3). The Tobit model enables us to assess the hypothesis of this study about the impact of exogenous variables on the efficiency of university third mission activities (Kempkes \& Pohl, 2008). A range of factors shape the ability of a university to engage in third mission activities: geographical location, historical context, the organizational structure of the university, its management vision, and the nature of the stakeholders it is seeking to engage with (Fonseca, 2019). From this perspective, medical school, foundation year, city, and ranking are selected as exogenous factors impacting on research universities' third mission efficiency in Turkey since it was predicted that universities with medical schools with an older foundation date and located in big cities might carry out more third mission activities in Turkey compared to others. On the other hand, ranking was used as an exogenous variable, which might give some insights into the linkage between the research mission and the third mission of universities since there is no data for direct measurement of the efficiency of the research dimension of the third mission activities of universities. Because international ranking scores are mostly calculated based on the research activities of universities, the Times Higher Education (THE) Word University Rankings was used for exogenous variables in the Tobit model. The World University Rankings are the global performance tables that 
rank research-intensive universities in which the total weight of research related activities (research, citations, international outlook, and knowledge transfer) is nearly $70 \%$ (THE, 2019).

Therefore, dummy variables were used in the regression to analyze how having medical schools, establishment in the cities of Ankara, Istanbul, and Izmir, founded before 1981 or after the establishment of CoHE, and placed in the international ranking list might affect the efficiency of third mission activities. The results showed that only the foundation year of universities has a statistically significant effect on the efficiency of third mission activities concerning the social dimension; in other words, research universities founded before 1981 might have displayed better performance than others. In particular, the possibility of third mission efficiency is greater for the older ones than expected (Innocenti et al., 2019). On the basis of this result, location and having a medical school have no impact on the efficiency of the third mission activities of research universities in Turkey. Besides, there is no international ranking impact on the universities' third mission activities in terms of social dimension, as expected, most probably because the weight of third mission indicators in total scores is little or none (Urdari et al., 2017; THE, 2019).

Table 3. Tobit Model Results

\begin{tabular}{|c|c|c|c|c|}
\hline \multicolumn{5}{|c|}{ Dependent Variable: Overall Efficiency Score } \\
\hline Variables & Coefficient & Standard Error & z-Statistics & Probability \\
\hline Ranking & 0.011654 & 0.159923 & 0.072871 & 0.9419 \\
\hline Foundation Year & $0.459776 * * *$ & 0.176084 & 2.611 .112 & 0.0090 \\
\hline City & 0.209246 & 0.144380 & 1.449 .269 & 0.1473 \\
\hline Medical School & -0.075560 & 0.156602 & -0.482497 & 0.6295 \\
\hline \multicolumn{5}{|l|}{ Error Distribution } \\
\hline SCALE: C(5) & $0.314878 * * *$ & 0.055663 & 5.656 .854 & 0.0000 \\
\hline Mean dependent variable & 0.421813 & Standard deviation dependent var & & 0.393326 \\
\hline Standard error of regression & 0.382639 & Akaike info criterion & & 1.151 .736 \\
\hline Sum squared residuals & 1.610 .541 & Schwarz criterion & & 1.393 .170 \\
\hline Log likelihood & -4.213 .886 & Hannan-Quinn criterion & & 1.164 .099 \\
\hline Avg. log likelihood & -0.263368 & & & \\
\hline
\end{tabular}

Note: $* * * 1 \%, * * 5 \%, *$ the $10 \%$ significance level.

\section{CONCLUSION}

This study evaluated the efficiency of the third mission activities of sixteen research universities (eleven of them are research universities and five of them are candidate research universities) with regard to the social dimension in Turkey for 2019 by applying the DEA method. Then, the Tobit model was used to identify the exogenous factors that affected the third mission efficiency of universities. The results showed that only four research universities out of sixteen were efficient relative to others, considering human and financial inputs as they conducted their third mission activities related to the social dimension. Besides, the findings indicated that there was a positively significant relationship between the universities' foundation years (before 1981) and their efficiency scores.

Although increasing performance in third mission activities is not a main priority of research universities, the contribution of both research and social dimensions of the third mission activities to university performance should not be ignored. Hence, it is possible to deduce that Turkey's research universities need effective policies to improve their performance in the third mission along with the research mission. Since the third mission of universities is still a new paradigm change for universities in Turkey, it requires a certain time to make its effects felt on higher education. For this reason, the suitability of the existing indicators defined by the CoHE and THEQC for assessing third mission performance is wide open to debate. As a result, more collaboration between the CoHE and THEQC and research universities is needed to improve the third mission performance in Turkey. In this context, new indicators for monitoring and evaluating the third mission performance of universities might be developed. Besides, the current indicators employed by global international university rankings should place more emphasis on universities' third mission globally. 
On the other hand, this study also has some limitations. Due to a lack of data in this study area, it is difficult to assess current practices and develop policies to improve the performance of universities' third mission activities. Lastly, increasing the weight of third mission activities, especially for the social dimension, in the leading international rankings might be beneficial to improve the performance of research universities in this area. Therefore, universities should give more attention to data collection for their third mission activities in Turkey and the world.

However, the CoHE and THEQC reports are only interested in the social dimension of the third mission of Turkish universities. As a result, potentially profitable research mission activities directly related to universities' third mission, such as patents, copyright, technology transfer, and innovations, might be included as an output to the formulated model in this study. Because of the financial pressures on universities, profit-oriented research activities in research universities have increased in recent years (Altbach, 2009). Because only ranking was used as a proxy for examining the relationship between the third mission and the research mission of research universities in Turkey, other proxies might be developed for investigation. Moreover, future studies might focus more on these dual dimensions of the third mission activities of research universities in Turkey. In short, the findings of this study are likely to provide university administrations with critical managerial information on their performance of third mission activities.

\section{DECLARATION OF THE AUTHORS}

Declaration of Contribution Rate: The authors have equal contributions.

Declaration of Support and Thanksgiving: No support is taken from any institution or organization.

Declaration of Conflict: There is no potential conflict of interest in the study.

\section{REFERENCES}

Abbott, M., \& Doucouliagos, C. (2003). The efficiency of Australian universities: A data envelopment analysis. Economics of Education Review, 22(1), 89-97.

Agasisti, T., \& Bonomi, F. (2014). Benchmarking universities' efficiency indicators in the presence of internal heterogeneity. Studies in Higher Education, 39(7), 1237-1255.

Agasisti, T., Barra, C., \& Zotti, R. (2019). Research, knowledge transfer, and innovation: The effect of Italian universities' efficiency on local economic development 2006-2012. Journal of Regional Science, 59, 819-849.

Alliance of Turkish Research Universities [ALTRU]. (2016). International competition in research universities and higher education, research and innovation. Retrieved September 11, 2021 from https://pdo.metu.edu.tr/system/files/duyuru/TAUG_Arastirma_Universiteleri_ve_Yuksekogretim_Arast irma_ve Inovasyonda_Uluslararasi_Rekabet_Raporu_2016.pdf

Altbach, P. G. (2009). Peripheries and centers: research universities in developing countries. Asia Pacific Education Review, 10, 15-27.

Banker, R. D., Charnes, A., \& Cooper, W. W. (1984). Some models for estimating technical and scale inefficiencies in data envelopment analysis. Management Science, 30(9), 1078-1092.

Barra, C., \& Zotti, R. (2016). A directional distance approach applied to higher education: An analysis of teachingrelated output efficiency. Annals of Public and Cooperative Economics, 87(2), 145-173.

Baysal, M. E., Alçılar, B., Çerçioğlu, H., \& Toklu, B. (2005). Türkiye'deki devlet üniversitelerinin 2004 yılı performanslarının veri zarflama analizi yöntemiyle belirlenip buna göre 2005 yılı bütçe tahsislerinin yapılması. Sakarya Üniversitesi Fen Bilimleri Enstitüsü Dergisi, 9(1), 67-73.

Bierens, H. J. (2014). The tobit model. Retrieved September 30, 2021 from http://php.scripts.psu.edu/users/h/x/hxb11/EasyRegTours/TOBIT_Tourfiles/TOBIT.PDF

Brundenius C., \& Göransson B. (2011). The three missions of universities: A synthesis of UniDev project findings. In B. Göransson, \& C. Brundenius (Ed.), Universities in transition: Insight and innovation in international development (p. 329-352). Springer. 
Süleyman Demirel Üniversitesi Vizyoner Dergisi, Yıl: 2022, Cilt: 13, Sayı: 33, 110-121.

Süleyman Demirel University Visionary Journal, Year: 2022, Volume: 13, No: 33, 110-121.

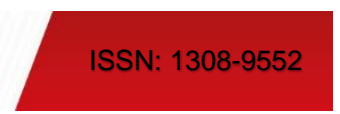

Carrion, A., García-Gutiérrez, V. R., Bas, M.C, \& Carot, J. M. (2012). A new methodology for measuring third mission activities of universities. Proceedings of 6th International Technology, Education and Development Conference INTED 2012 (p. 1218-1223). IATED, Valencia, Spain.

Charnes, A., Cooper, W. W., \& Rhodes, E. (1978). Measuring the efficiency of decision-making units. European Journal of Operational Research, 2, 429-444.

Charnes, A., Cooper, W., Lewin, A. Y., \& Seiford, L. M. (1994). Data envelopment analysis: Theory, methodology and applications. Kluwer Academic Publishers.

Coelli, T. (1996). A guide to DEAP version 2.1: A data envelopment analysis (computer) program (No. 08). CEPA Working Papers, Armidale.

Compagnucci, L., \& Spigarelli, F. (2020). The third mission of the university: A systematic literature review on potentials and constraints. Technological Forecasting and Social Change, 16, 120284. https://doi.org/10.1016/j.techfore.2020.120284

Council of Higher Education [CoHE]. (2020). Yükseköğretimde ihtisaslaşma ve misyon farklilaşmasi araştirma üniversiteleri. YÖK.

Council of Higher Education [CoHE]. (2021a). Higher education information and management system. Retrieved September 17, 2021 from https://istatistik.yok.gov.tr/

Council of Higher Education [CoHE]. (2021b). University monitoring and evaluation report. Retrieved September 21, 2021 from https://www.yok.gov.tr/universiteler/izleme-ve-degerlendirme-raporlari

Council of Higher Education [CoHE]. (2021c). YÖK üstün başarı ödülleri. Retrieved September 23, 2021 from https://odul.yok.gov.tr/

Engert, F. (1996). The reporting of school district efficiency: The adequacy of ratio measures. Public Budgeting and Financial Management, 8, 247-271.

Fonseca, L. (2019). Third mission accomplished? Why are universities bad at engaging with local and regional government and what we can do about it. Retrieved September 11, 2021 from https://blogs.lse.ac.uk/impactofsocialsciences/2019/03/13/third-mission-accomplished-why-areuniversities-bad-at-engaging-with-local-and-regional-government-and-what-we-can-do-about-it/

Frondizi, R., Fantauzzi, C., Colasanti, N., \& Fiorani, G. (2019). The evaluation of universities' third mission and intellectual capital: Theoretical analysis and application to Italy. Sustainability, 11, 3455. https://doi.org/10.3390/su11123455

Giuri, P., Munari, F., Scandura, A., \& Toschi, L. (2019). The strategic orientation of universities in knowledge transfer activities. Technological Forecasting and Social Change, 138, 261-278.

Günay, A. (2021). A case study on evaluating regional development-oriented universities' contribution to society activities in Turkey. Üniversite Araştırmalarl Dergisi, 4(2), 168-174. https://doi.org/10.26701/uad.975179

Günay, A., \& Dulupçu, M. A. (2019). Measurement of financial efficiency and productivity of Turkish public universities by using non-parametric methods. Journal of Applied Research in Higher Education, 11(4), 876-896. https://doi.org/10.1108/JARHE-07-2018-0116

Günay, A., \& Yüksel-Haliloğlu, E. (2018). A case study on measuring research efficiency of public universities in Turkey. Journal of University Research, 1(2), 36-42.

Hsiao, H. C., Chang, H., Cianci, A. M., \& Huang, L. H. (2010). First financial restructuring and operating efficiency: Evidence from Taiwanese commercial banks. Journal of Banking and Finance, 34(7), 1461- 1471.

Innocenti, D., Matousek, M. R., \& Tzeremes, N. G. (2019). The interconnections of academic research and universities "third mission": Evidence from the UK. Research Policy, 48.

Jager, A., \& Kopper, J. (2014). Third mission potential in higher education: Measuring the regional focus of different types of HEIs. Review of Regional Research, 34, 95-118. 
Süleyman Demirel Üniversitesi Vizyoner Dergisi, Yıl: 2022, Cilt: 13, Sayı: 33, 110-121.

Süleyman Demirel University Visionary Journal, Year: 2022, Volume: 13, No: 33, 110-121.

Johnes, J., \& Johnes, G. (1995). Research funding and performance in UK university departments of economics: A frontier analysis. Economics of Education Review, 14(4), 301-314.

Johnes, J., \& Yu, L. (2008). Measuring the research performance of Chinese higher education institutions using data envelopment analysis. China Economic Review, 19(4), 679-696.

Kao, M., Lin, C., Hsu, P., \& Chen, Y. (2011). Impact of the financial crisis and risk management on performance of financial holding companies in Taiwan. World Academy of Science, Engineering and Technology, 50, 413-417.

Karacabey, A. (2001). Veri zarflama analizi. Ankara Üniversitesi Siyasal Bilgiler Fakültesi Gelişme ve Toplum Araştırmaları Merkezi Tartışma Metinleri, 33, 1-12.

Karacaer, Ş. (1998). Antalya yöresindeki 4 ve 5 yıldızlı otellerde toplam etkinlik ölçümü: Bir veri zarflama analizi uygulaması [Yüksek Lisans Tezi]. Hacettepe Üniversitesi.

Kempkes, K., \& Pohl, C. (2008). Do institutions matter for university cost efficiency? Evidence from Germany. CESifo Economic Studies, 54, 177-203.

Kesten, A. (2019). Analysis of the missions of higher education institutions within the scope of third mission understanding. International Journal of Educational Methodology, 5(3), 387-400. https://doi.org/10.12973/ijem.5.3.387

Knudsen, M. P., Frederiksen, M. H., \& Goduscheit, R. C. (2019). New forms of engagement in third mission activities: A multi-level universitycentric approach. Innovation, 23(2), 209-240. https://doi.org/10.1080/14479338.2019.1670666

Kuo, J. S., \& Ho, Y. C. (2008). The cost efficiency impact of the university operation fund on public universities in Taiwan. Economics of Education Review, 27(5), 603-612.

Laredo, P. (2007). Revisiting the third mission of universities: Toward a renewed categorization of university activities?. Higher Education Policy, 20(4), 441-456.

Leydesdorff, L., \& Etzkowitz, H. (1996). Emergence of a Triple Helix of university—industry—government relations. Science and Public Policy, 23(5), 279-286. https://doi.org/10.1093/spp/23.5.279

Mammadov, R., \& Aypay, A. (2020). Efficiency analysis of research universities in Turkey. International Journal of Educational Development, 75, 102176. https://doi.org/10.1016/j.ijedudev.2020.102176

Marhl, M., \& Pausits, A. (2011). Third mission indicators for new ranking methodologies. Evaluation in Higher Education, 5(1), 43-64.

Matthews, K., \& Mahadzir, I. (2006). Efficiency and productivity growth of domestic and foreign commercial banks in Malaysia (E2006/2). Cardiff Economics Working Papers.

Mikušová, P. (2017). Measuring the efficiency of the Czech public higher education institutions: an application of DEA. Journal on Efficiency and Responsibility in Education and Science, 10(2), 58-63.

Molas-Gallart, J., \& Castro-Martinez, E. (2007). Ambiguity and conflict in the development of "Third Mission" indicators. Research Evaluation, 16(4), 321-330.

MoNE. (2019). National education statistics formal education 2018/'19. Retrieved September 25, 2021 from http://sgb.meb.gov.tr/www/icerik_goruntule.php?KNO=361

Montesinos, P., Carot, J. M., Martinez, J.-.M., \& Mora, F. (2008). Third mission ranking for world class universities: Beyond teaching and research. Higher Education in Europe, 33(2-3), 259-271.

Mora, J.-G., Ferreira, C., Vidal, J., \& Vieira, M.-J. (2015). Higher education in Albania: Developing third mission activities. Tertiary Education and Management, 21(1), 29-40. https://doi.org/10.1080/13583883.2014.994556

Munoz, D. A. (2016). Assessing the research efficiency of higher education institutions in Chile: A data envelopment analysis approach. International Journal of Educational Management, 30(6), 809-825. 
Ng, Y. C., \& Li, S. K. (2000). Measuring the research performance of Chinese higher education institutions: An application of data envelopment analysis. Education Economics, 8(2), 139-156.

Oruç, K. O., Çuhadar, M., Kilinç, M., \& Osmancik, S. (2014). Veri zarflama analizi ile mermer işletmelerinin etkinlik ölçümü. 15th International Symposium on Econometrics, Operations Research and Statistics (p. 977-994). Isparta., Turkey.

Papadimitriou, A. (2020). Beyond rhetoric: reinventing the public mission of higher education. Tertiary Education and Management, 26, 1-4.

Rosli, A., \& Rossi, F. (2016). Third-mission policy goals and incentives from performance-based funding: Are they aligned?. Research Evaluation, 25, 427-441.

Rubens, A., Spigarelli, F., Cavicchi, A., \&Rinaldi, C. (2017). Universities' third mission and the entrepreneurial university and the challenges they bring to higher education institutions. Journal of Enterprising Communities: People and Places in the Global Economy, 11(03), 354-372. https://doi.org/10.1108/JEC01-2017-0006

Sánchez Barrioluengo, M., Uyarra, E., \& Kitagawa, F. (2016). Understanding the dynamics of triple helix interactions (WP32). The Case of English Higher Education Institution. Birkbeck Centre for Innovation Management Research (CIMR) Working Paper Series.

Spiel, C. (2017). How education can promote social progress. Retrieved September 21, 2021 from http://iauptriennial2017.com/wp-content/uploads/2017/07/ys-1-keynote-spiel-christiane.pdf

Times Higher Education [THE]. (2019). World university rankings 2019. Retrieved August 9, 2021 from https://www.timeshighereducation.com/world-university-rankings

Tobin, J. (1958). Estimation of relationships for limited dependent variables. Econometrica: Journal of the Econometric Society, 26(1), 24-36. https://doi.org/10.2307/1907382.

Tran, Carolyn-Dung, T. T., \& Villano, R. A. (2018). Financial efficiency of tertiary education institutions: A second-stage dynamic network Data Envelopment Analysis method. The Singapore Economic Review, 63(1), 1-22.

Trencher, G., Yarime, M., McCormick, K. B., Doll, C. N. H., \& Kraines, S. B. (2014). Beyond the third mission: Exploring the emerging university function of co-creation for sustainability. Science and Public Policy 4l(2), 151-179.

Turkish Higher Education Quality Council [THEQC]. (2021). Institutional indicator reports. Retrieved September 26, 2021 from https://yokak.gov.tr/raporlar/kurum-gosterge-raporlari

Urdari, C., Farcas, T. V., \& Tiron-Tudor, A. (2017). Assessing the legitimacy of HEIs' contributions to society. Sustainability Accounting, Management and Policy Journal, 8(2), 191-215. https://doi.org/10.1108/sampj-12-2015-0108

Weihrich, H., \& Koontz, H. (2005). Management: A global perspective. Tata McGraw-Hill.

Worthington, A. (2001). An empirical survey of frontier efficiency measurement techniques in education. Education Economics, 9(3), 245-268.

Yeşilyurt, C. (2009). Türkiye'deki iktisat bölümlerinin göreceli performanslarının veri zarflama analizi yöntemiyle ölçülmesi: KPSS 2007 verilerine dayalı bir uygulama. Atatürk Üniversitesi İktisadi ve İdari Bilimler Dergisi, 23(4), 135-147.

Zomer, A., \& Benneworth, P. (2011). The rise of the university's third mission. In J. Enders et al. (Ed.), Reform of higher education in Europe (p. 81-101), Sense Publishers. 